and the other of the tholos (or beehive) type frequent in Greece but not in Crete. M. S. F. Hood supplies a detriled commentary on another, well-stocked Cretan chamber tomb. M. Pope offers the cryptographers four Cretan axe-heads with inscriptions in the undeciphered 'Linear $A$ ' writing. A. J. B. Wace reports on his last campaign at Mycenae in 1955 with important observations on the "Treasury of Atreus', the houses and the palace; V. R. d'A. Desborough adds an account on two graves of the early Iron Age, one containing what may be the first Hellenic lamp yet recognized. In epigraphy, A. M. Woodward continues his notes on Athenian inscriptions. G. E. Bean reports on a foray into the south-west of Hellenistic and Roman Turkey. L. H. Jeffery contributes a new and improved publication of an inscription of the sixth century B.c. from Chios, the earliest document of democracy, whatever that politicel term meent. W. G. Forrest does some ingenious calculations about liquid measures in Chios. J. Boardman offers variety : first he gives a judicious account of a not very productive excavation at Delphinion in Chios, then he puts a partisan case for the making of fine Greek pottery at Naucratis in Egypt.

The British School at Athens with old-fashioned good sense publishes its "Annual" with a stout binding. The printing, too, is good and the illustrations are generous.

R. M. Cook

\section{THERMAL ANALYSIS OF CLAYS}

The Differential Thermal Investigation of Clays Edited by Robert C. Mackenzie. Pp. xii +456 . (London: Mineralogical Society, 1957.) 608.; 9 dollars.

THIS volume has been prepared by the Clay Minerals Group of the Mineralogical Society as a companion or complementary work to its "X-Ray Identification and Crystal Structures of Clay Minerals", which appeared in 1951 (see Nature, 170, $337 ; 1952)$. It differs from the latter in one respect, however, for it considers not only the clay minerals, but also the minerals in clays. Since clays and other raw materials, to which the methods of differential thermal analysis described are applicable, are very frequently not mono-mineralic, this widening of the field covered is important.

As the editor points out, recognition of the importance of thermal properties in the identification of minerals is by no means a new conception, for it goes back to the eighteenth century. That important developments did not take place until many years later was due to the difficulties in applying the conception with success. These were, originally, the inaccuracies of early pyrometry and, in the case of the clay minerals especially, the small size of clay particles. As with other sciences, important advances have followed improvements in the technical methods of investigation; and a major advance was initiated by $L e$ Chatelier, who developed the thermocouple as an accurate means of measuring temperature, and applied it to the investigation of certain clay minerals in 1887. From time to time, since then, further progress was made; but it is only in the past thirty or so years, during which time the basic structures of most of the clay minerals have become known, that the method has come into general use. Although at present $\mathrm{X}$-ray diffraction is admittedly the most valuable single method for the investigation of clay mineralogy, differential thermal analysis of clay minerals, and raw materials containing clay minerals, has grown rapidly in importance as an auxiliary method of investigation.

This study of the subject has been prepared under the general editorship of Dr. R. C. Mackenzie of the Macaulay Institute for Soil Research, Aberdeen, but there are twenty-two contributors, from various research centres, in Great Britain and abroad, who have made special studies of different aspects of the subject. Dr. Mackenzie contributes an introductory chapter on the various thermal methods now in use. The next two chapters deal with the apparatus and techniques employed, and with the theoretical and quantitative interpretation of results. There follow twelve chapters on particular mineral groups, including, as well as the minerals generally recognized as clay minerals : the various forms of silica; oxides of iron, aluminium and manganese; carbonates; and 'other minerals', such as certain sulphides, halides, phosphates, etc. There is also a chapter on carbonaceous materials, which may assume importance as impurities in, for example, fireclays and ball clays. The final chapter discusses the technical applications of differential thermal analysis for soil science, geology, and the ceramic, chemical and mining industries. Each chapter concludes with a bibliography.

The information here brought together has been derived from many scattered sources, including original papers written in languages other than English. The book forms a valuable work of reference which must prove useful to research workers in a number of fields, and the authors and editor are to be congratulated on its production.

\section{A UNIFIED SCIENCE OF LIFE}

Life

An Introduction to Biology. By George Gaylord Simpson, Colin S. Pittendrigh and Lewis H. Tiffany. Pp. xiv +845 . (London: Routledge and Kegan Paul, Ltd., 1958.) 50s. net.

MERICAN writers have a remarkable facility A either for producing precise works of magnificent quality or verbose volumes which have little appeal in Great Britain. "Life" belongs to the former group and bears comparison with any text-book of biology yet produced in the English language. Other authors have attempted to produce a unified science of biology but have achieved little more than an illicit union of botany and zoology. The authors of "Life" believe that general biology has a body of established and working principles and that every rational human being should have a basic acquaintance with these principles. These principles are given considerable prominence throughout the text, and supporting facts are used to show how the principles arise from them.

The book is divided into nine main sections. After an introductory section, which makes a survey of the living world, the place of biology in the whole field of science is considered and this leads to a description of the foundations of modern biology. Then follow accounts of the unit of living organization, of how organisms are maintained and integrated, the continuity of life, the mechanisms of evolution, the amazing diversity of living organisms, the life of 